\title{
Middle and Junior Managers' Perceptions of Perceived Organisational Support in the South African Soccer Domestic Leagues
}

\author{
Keyser, E \\ North-West University (Vaal Triangle Campus), Faculty of Human Sciences \\ Email: elsabe.keyser@nwu.ac.za \\ Maseko, J \\ Vaal University of Technology, Faculty of Management Sciences, \\ Email: johannes@vut.ac.za
}

Surujlal, J

North-West University (Vaal Triangle Campus), Faculty of Economic Sciences and Information Technology,

Doi:10.5901/mjss.2014.v5n13p126

Email: babs.Surujlal@nwu.ac.za

\begin{abstract}
The concept of perceived organisational support has attracted considerable interest as an attempt to understand the intensity and stability of employee loyalty and dedication to the organisation. The same organisational principles are applicable sport organisations like soccer clubs since their ultimate success depends to a great extent on their human resources. It is important for soccer clubs to attract and retain staff with adequate skills to enhance the brand and image of the club. The purpose of this study was to compare middle and lower managers' perceived organisational support and demographical information and how they perceive organisational support from the soccer clubs. The study adopted a non-probability convenience sampling method to recruit junior and middle managers in the Premier Soccer League (PSL) in South Africa. Two hundred questionnaires were administered to middle and junior management. One hundred and fifteen (58\%) usable questionnaires were returned. Perceived organisational support was assessed by means of the Perceived Organisational Support Questionnaire. One-way analysis of variance indicates that there were no significant difference between gender and middle managers, but there are significant differences for lower managers and gender. A significant difference exists between middle and lower managers regarding to their years of experience, age and qualifications and experience of perceived organisational support.
\end{abstract}

Keywords: Perceived organisational support, middle managers, lower managers, age, gender, qualification

\section{Introduction}

Sport organisations are consistently encountering significant competition in the face of international competition, increased sport participation, increased sponsorship, increased visibility of sport and greater levels spectatorship. In order to address this immense challenge sport organisations are forced to redirect their attention to what is regarded as one of the most important assets for most organisations - their human resources.

The fact that organisational success is dependent on its employees (Ghani, 2006), makes it necessary for organisations to provide appropriate support to their employees so that their productivity increases. Colakoglu, Culha and Atay (2010) view organisational support as one of the most important organisational concepts that help retain employees in an organisation, because of its potential to increase their job satisfaction, job security and organisational commitment. Organisational support is defined as the degree to which employees perceived that their organisation was concerned with their health and well-being as well as with the reduction of conflict between employees' personal and professional life (Grant-Vallonea \& Ensherb, 2001). Perceived organisational support (POS) is the employees' view of how much the organisation values their contribution and cares about them (Allen, Armstrong, Reid \& Riemenschneider, 2008). The employment relationship is a reciprocal exchange relationship that reveals relative interaction, dependence and extends beyond a formal contract of employment.

Given the dynamic and competitive environment in which organisations operate, it is not surprising that organisations make every attempt to retain competent employees (Colakoglu et al., 2010) to increase their chances of success. The competitive environment, however, often also influences an employee to compare his/her organisation with other organisations as well as compare future positions (Kanaga \& Browning, 2007). This process which is used by 
employees as a psychological process affects perception of their organisational support.

\section{Perceived Organisational Support (POS)}

A great deal of research has been conducted on the concept of organisational commitment which is associated with organisational support. Generally employers who recognise dedication and loyalty in their employees tend to be supportive of such employees. Being valued by the organisation can yield such benefits as increased approval and respect, higher pay and more chances for promotion, as well as access to information and other forms of aid needed to better carry out one's job (Rhoades \& Eisenberger, 2002). Organisational commitment and perceived organisational support (POS) embodies an attitudinal response to the organisation as a whole (Shore \& Tetrich, 1991). It could therefore be argued that POS should also be distinct from employment satisfaction. Employees become attached to an organisation because they consider a beneficial or equitable exchange relationship between their contributions to the organisation and the rewards they receive for service rendered. Therefore, attachment to an organisation is a state that can arise through the accumulation of a series of actions from the organisation.

In recent years, POS has received increased attention from researchers and practitioners in an attempt to understand the intensity and stability of employee loyalty and dedication to the organisation. Several studies (e.g. De Croon, Sluiter, Blonk, Broersen \& Frings-Dresen, 2004; Hardy, Woods \& Wall, 2003; Beehr, Jex, Stacy \& Murray, 2000) have highlighted the detrimental effects of stress and psychological distress on individuals and organisations, which include poor physical health, reduced performance, absenteeism, and turnover. In the light of the afore-mentioned it is important for employees to feel that their employers understand the challenges they face and provide support and assistance to help them to integrate work with the rest of their life. Employees have a need to determine whether, and to what extent an organisation recognises and rewards their efforts, support their socio-emotional needs, and are willing to help them on request.

The Organisational Support Theory (Rhoades \&Eisenberger, 2002) suggests that employees; general perception of the extent to which an organisation values their input and cares about their well-being influences their obligation to work towards assisting the organisation to achieve its objectives. In return for a high level of support, employees work harder to help their organisation reach its goals, providing loyalty and effort in return for material and social rewards (Aselage \& Eisenberger, 2003). Some of the positive behaviourial outcomes associated with POS are increases in in-role and extra-role performance and decreases in withdrawal behaviours such as absenteeism and turnover (Rhoades \& Eisenberger, 2002; Shore \& Shore, 1995). Actually, when employees believe that the organisation is committed to them, they consider themselves obligated to be enormously committed to the organisation (Eisenberger, Huntington, Hutchison \& Sowa, 1986).

Employees may use organisational support to review the potential gain of material and symbolic benefits that would results from activities favoured by the organisation (Eisenberger, Fasolo \& Davis-LaMastro, 1990). Also, employees' belief that the organisation has a general positive or negative orientation toward them that encompasses both recognition of their contributions and concern for their welfare would contribute to their psychological well-being and positive orientation to the organisation.

Allen, Eby, Poteet, Lentz and Lima (2004) discovered that employees with mentor-support reported relatively higher levels of job satisfaction, organisational commitment, compensation and promotions revealing the potential significance of having a mentor for accomplishing both subjective and objective career benefits. Baranik, Roling and Eby (2010) views supervisory mentors as agents of the organization, therefore the support they provide for employees can be construed as organisational support. Orpen (1997), in agreement, speculated that if a mentor is viewed as a representative of the organisation and support from the mentor is high it may be likely that employees would display increased organisational commitment. In addition, Forret and de Janasz (2005) found that employees with mentors perceived their organisation's culture to be more supportive of work and family than did employees without mentors.

Work-related support from the mentor may promote positive beliefs and attitudes towards the mentor, which in turn contributes to the belief and trust that the organisation recognizes the importance of the employee's well-being. Hence there is a return on investment in terms of productivity and engagement from the employee as a result of POS. Similarly, by preparing an employee for long-term positive organisational experiences, career-related mentoring support is likely to signal to the employee that the organisation is invested in his or her career development, which again should facilitate the development of POS. Johnston (1995) found POS to be a significant predictor of employees' behavioural intentions, implying that high POS will lead to intention to stay and low POS will lead to intention to leave. 


\section{Business of Sport Organisations Like Soccer Clubs}

The soccer industry is rather a labour-intensive industry, mainly because its continued existence is dependent on the availability of exceptional good quality employees. The presence of employees is crucial to deliver, operate, and manage the soccer business/product for survival and for a competitive advantage. In organisations such as soccer clubs advantage is dependent on multiple factors, such as location, facilities, leadership, and management. Equally important is the more tacit capital of organisations, namely their employees, and the support which employees receive from their organisations. Through services, employees become directly involved in the creation of value both for customers (e.g. spectators, fans, sponsors, athletes) and for the organisation (soccer club), thereby having a direct effect on the organisation's market performance.

The concept of organisational support has attracted considerable interest as an attempt to understand the intensity and stability of employee loyalty and dedication to the organisation. The same organisational principles are applicable sport organisations like soccer clubs since their ultimate success depends entirely on their human resource. It is important for soccer clubs to attract and retain staff with adequate skills to enhance the brand and image of the club. Soccer clubs are becoming more and more preoccupied with their image since there is increasing recognition that image has the power to influence the behaviour of all those involved with a sporting organisation, its members, event spectators, journalists, sponsors and fans. Indeed, some consider that an image has the potential to impact behavior of consumer and therefore to lead to adjustment in brand equity. Employees are an essential element to anchor organisational image. Hence, it is important that the organisation constantly retains and motivates its employees to preserve its image. The aim of many clubs is to become 'global football brands'.

With more than two million active players and more than 54 percent of the national population following football, this sport is the most popular and widely practiced sport in South Africa (Saayman \& Rossouw, 2008). It is interesting to notice that soccer popularity and success depends highly on human capital acumen. To be successful in delivering their businesses, soccer clubs are required to have capable employees within their structures. Soccer clubs have become avenues for mastering business and change and employees are seen as custodians to carry the responsibility of fundamental ways of conducting business. The potential employees includes chairman of the soccer clubs, directors, team managers, who are responsible for the strategic management of clubs and general employees who are responsible for daily administration of soccer clubs.

Sport has a specific nature that sets it apart from any other field of business activity, because of its important social, educational and cultural functions (Adonis, 2011). Hoye, Smith, Stewart, Nicholson and Westrebeek (2005) noted that sport has evolved from amateur part-time activity to significant industry with organisations and individuals investing money in the sector. Indeed the success of soccer clubs in entirely depends in the manner in which soccer is produced and consumed and the manner in which soccer matches and clubs are managed at all levels. Hence, the significance of management and administration of soccer clubs can be regarded as the application of business and management knowledge to sport activities. The organisation sets the strategic plan through the development of strategies to guide the organisational goals and objectives in order to satisfy the organisational stakeholders. The internal stakeholders include managers, employees, owners and their representatives.

\section{Purpose of the Study}

The objective of this study is to investigate middle and junior managers' perceptions of organisational support offered by South African soccer clubs. The organisational support offered by soccer clubs to their employees is of paramount importance because their success is relative to the POS they experience.

\section{Methodology}

\subsection{Research Approach}

A quantitative research design was adopted for the current study. Quantitative research involves quantifying data and applying some form of statistical analysis (Malhotra, 2007) to measure behaviour, knowledge, perceptions, opinions or attitudes (Cooper \& Schindler, 2006). Furthermore, a quantitative research approach is specific, well structured, and provides avenues for testing validity and reliability (Kumar, 2011). 


\subsection{Sample}

The target population for this study was middle and junior managers of football clubs in the domestic soccer leagues in South Africa. As the domestic leagues are governed by the South African Soccer Association (SAFA), they are deemed to be authentic sport organisations governed by the rules and regulations of SAFA. In the context of this study a junior manager of a soccer club is responsible for the smooth day-to-day running of the club. The junior manager would oversee the players and their requirements as well as perform other player-related functions. On the other hand, the middle manager of a soccer club is a manager to whom the junior managers are subordinate. They would typically also oversee a few departments (e.g. finance, purchasing, sponsorship) in the club. To be eligible to participate in the study the following criteria were applied: managers were employed by their current club for at least one year and spent at least sixty percent of their time performing management functions. A non-probability convenience sampling method was used to recruit participants for the study. A total of 200 questionnaires were administered to the sample. Of these 115 (58\%) usable ones were returned.

\subsection{Instrument and procedures}

Based on a comprehensive literature study on organisational support, a questionnaire was designed. In Section A questions requesting respondents' demographic information were included. Section B of the questionnaire contained items which focused specifically on the attitudes towards organisation. Items in this section were scored on a 5-point Likert scale anchored at 1 (strongly disagree), 2 (slightly disagree), 3 (neither agree nor disagree), 4 (slightly agree), 5 (strongly agree). Section $\mathrm{C}$ of the questionnaire comprised items measuring Perceived Organisational Support (POS) (Eisenberger et al., 1986). Items in this section were scored on a 6-point Likert scale anchored at 0 (strongly disagree), 1 (moderately disagree), 2 (slightly disagree), 3 (neither agree nor disagree), 4 (slightly agree), 5 (moderately agree), 6 (strongly agree). One of the researchers who had an extensive network to the management at most of the soccer clubs in the domestic league administered the questionnaires to middle and junior managers at various clubs in the domestic leagues. Two methods of administration were employed. Questionnaires were either e-mailed to potential respondents or hand-delivered to them. In instances where they were hand delivered, questionnaires were collected immediately after they were completed.

\subsection{Data analysis}

Data were analysed using the Statistical Package for Social Sciences (SPSS - Version 22). The first phase of the data analysis involved an assessment of the construct validity of the POS. Prior to principal factor analysis principal component extraction was done to estimate the number of factors, the presence of outliers and factorability of the matrices. The eigenvalues and scree plot were studied to determine the number of factors. A principal axis factor analysis with a direct oblimin rotation was conducted to extract the factors (Tabachnick \& Fidell, 2001). Cronbach alpha coefficients were computed to assess the internal consistency of the scales. Hair, Anderson, Tatham and Black (1998) explains that generally the agreed lower limits for the Cronbach alpha coefficient is 0.70 . One way analysis of variance (ANOVA) was performed to determine whether there were statistically significant differences between perceived organisational support and management level (middle and junior managers).

\subsection{Ethical considerations}

A cover letter explaining the purpose of the study as well as informing the participants that their involvement in the study was voluntary was attached to the questionnaire Participants were also informed that their responses would be treated confidentially and that they would always remain anonymous.

\section{Results}

\subsection{Demographics}

In terms of the demographic composition of the sample more male participants $(n=78 ; 68 \%)$ than female participants $(n=37 ; 32 \%)$ completed the questionnaire. Of these fifty one $(n=51 ; 44 \%)$ were junior managers and sixty four $(n=64)$ were middle managers. Most of the participants $(n=91 ; 79 \%)$ had between two and four years' service at their respective organisations. All participants were 23 years and older. Of these the majority $(n=43,37 \%)$ were in the 28-32 year age 
group. With regard to their qualifications most participants ( $n=46 ; 40 \%)$ had a diploma.

\subsection{Construct validity}

A principal axis factor analysis with a direct oblimin rotation was carried out on the 17 items of the POS. The loadings of items on the one factors, communalities $\left(h^{2}\right)$, and percentage of variation explained by each question are reflected in Table 1.

Table 1: Factor Loadings, Communalities $\left(\mathrm{h}^{2}\right)$ and Percentage Variance for Principal Axis Factor Analysis on POS Items

\begin{tabular}{clcc}
\hline Item & \multicolumn{1}{c}{ Description } & $\mathrm{F}_{1}$ & $h^{2}$ \\
\hline 1 & My organisation values my contribution to its well-being. & 0.77 & 0.59 \\
2 & If my organisation could hire someone to replace me at a lower salary it would do so & -0.53 & 0.28 \\
3 & My organisation fails to appreciate any extra effort from me & -0.26 & 0.07 \\
4 & My organisation strongly considers my goals and values. & 0.86 & 0.74 \\
5 & My organisation would ignore any complaint from me & -0.60 & 0.36 \\
6 & My organisation disregards my best interest when it makes decisions that affect me & -0.66 & 0.44 \\
7 & Help is available from my organisation when I have a problem. & 0.93 & 0.86 \\
8 & My organisation really cares about my well-being. & 0.91 & 0.82 \\
9 & Even if I did the best job possible, my organisation would fail to notice. & -0.71 & 0.50 \\
10 & My organisation is willing to help me when I need a special favour. & 0.86 & 0.74 \\
11 & My organisation cares about my general satisfaction at work. & 0.91 & 0.83 \\
12 & If given the opportunity my organisation would take advantage of me & -0.59 & 0.35 \\
13 & My organisation shows very little concern for me & -0.78 & 0.62 \\
14 & My organisation cares about my opinions. & 0.89 & 0.80 \\
15 & My organisation takes pride in my accomplishments at work. & 0.91 & 0.82 \\
16 & My organisation tries to make my job as interesting as possible. & 0.94 & 0.88 \\
17 & My organisation is willing to extend itself in order to help me perform my job to the best of my ability. & 0.92 & 0.85 \\
& & Percentage variance & 62.05 \\
\hline
\end{tabular}

Inspection of Table 2 reveals that one factors were extracted, accounting for $62.05 \%$ of the total variance in the data. Only item 3 loaded below 0.30 and were removed from the questionnaire.

The descriptive statistics and alpha coefficients of the PCQ are reported in Table 2. The information reflected in Table 2 indicates negative distribution scores for POS question 5, 6, 7, 8 9, 13, 14, 15, 16 and 17. Furthermore, the results in Table 1 show acceptable Cronbach alpha coefficients for POS ( $\alpha=0.75)$.

Table 2: Descriptive Statistics and Cronbach Alpha Coefficients of the POS

\begin{tabular}{|c|c|c|c|c|c|}
\hline \multicolumn{2}{|r|}{ Item } & \multicolumn{3}{|c|}{ Mean SD Skewness Kurtosis } & \multirow{2}{*}{$\begin{array}{c}\text { Cronbach's Alpha } \\
\text { if Item Deleted }\end{array}$} \\
\hline \multirow{2}{*}{\multicolumn{2}{|c|}{$\begin{array}{l}\text { 1. My organisation values my contribution to its well-being. } \\
\text { 2. If my organisation could hire someone to replace me at a lower } \\
\text { salary it would do so }\end{array}$}} & 3.441 .53 & 0.05 & -1.43 & \\
\hline & & 3.691 .17 & 0.34 & -0.88 & 0.78 \\
\hline 3. & My organisation fails to appreciate any extra effort from me & 3.001 .35 & 0.52 & -0.44 & 0.76 \\
\hline 4. & My organisation strongly considers my goals and values. & 3.391 .32 & 0.15 & -1.53 & 0.70 \\
\hline 5. & My organisation would ignore any complaint from me & 3.421 .36 & -0.48 & -1.08 & 0.78 \\
\hline & $\begin{array}{l}\text { My organisation disregards my best interest when it makes } \\
\text { decisions that affect me }\end{array}$ & 3.501 .22 & -0.49 & -0.99 & 0.78 \\
\hline 7. & Help is available from my organisation when I have a problem. & 3.021 .26 & -0.03 & -1.17 & 0.71 \\
\hline 8. & My organisation really cares about my well-being. & 3.211 .47 & -0.05 & -1.60 & 0.67 \\
\hline & $\begin{array}{l}\text { Even if I did the best job possible, my organisation would fail to } \\
\text { notice. }\end{array}$ & 3.701 .49 & -0.35 & -0.98 & 0.79 \\
\hline & $\begin{array}{l}\text { My organisation is willing to help me when I need a special } \\
\text { favour. }\end{array}$ & 3.631 .77 & 0.16 & -1.66 & 0.70 \\
\hline & My organisation cares about my general satisfaction at work. & 3.111 .65 & 0.14 & -1.47 & 0.70 \\
\hline & $\begin{array}{l}\text { If given the opportunity my organisation would take advantage } \\
\text { of me }\end{array}$ & 3.801 .26 & 0.14 & -0.56 & 0.79 \\
\hline & My organisation shows very little concern for me & 3.571 .19 & -0.15 & -0.81 & 0.79 \\
\hline
\end{tabular}




\begin{tabular}{lllll}
\hline 14. My organisation cares about my opinions. & 3.571 .32 & -0.01 & -1.55 & 0.70 \\
15. My organisation takes pride in my accomplishments at work. & 3.511 .54 & -0.19 & -1.39 & 0.69 \\
16. My organisation tries to make my job as interesting as possible. & 3.431 .70 & -0.26 & -1.56 & 0.70 \\
17. My organisation is willing to extend itself in order to help me & 3.971 .70 & -0.14 & -1.75 & 0.70 \\
perform my job to the best of my ability. & &
\end{tabular}

To evaluate the variations in indicators, the length of the histogram plot and the presence of outliers and of extreme scores for middle and lower managers on POS are shown in Figure 1 and Figure 2. Figure 1 and Figure 2 shows some spread in the mean scores.

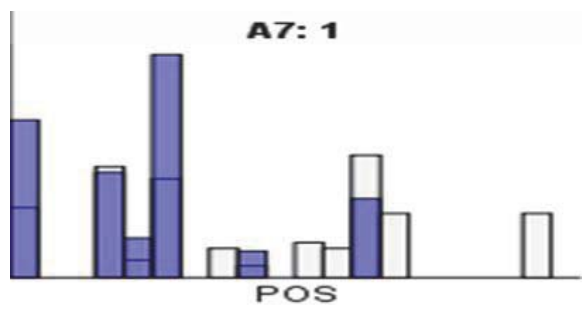

Figure 1: POS scores for lower managers

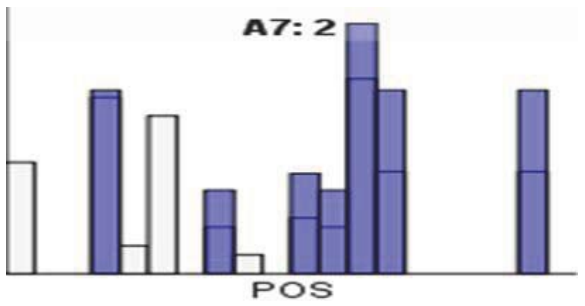

Figure 2: POS scores for middle managers

One-way ANOVA was performed to look at the differences between lower- and middle manager, demographical information and POS levels.

Table 4: One way ANOVA differences in POS Levels of Middle and Lower Managers

\begin{tabular}{lccccc}
\hline \multirow{2}{*}{ Item } & Type of manager & Mean & SD & $p$ & $\mathbf{F}$ \\
\hline \multirow{2}{*}{ Gender } & Lower & 1.41 & 0.50 & 0.00 & 43.39 \\
& Middle & 1.25 & 0.44 & - & - \\
\hline \multirow{2}{*}{ Years of experience } & Lower & 2.53 & 1.22 & 0.00 & 112.41 \\
& Middle & 3.83 & 1.29 & 0.00 & 392.42 \\
\cline { 2 - 6 } Age & Lower & 2.76 & 0.91 & 0.00 & 156.88 \\
& Middle & 3.88 & 0.79 & 0.00 & 140.57 \\
\cline { 2 - 6 } Qualification & Lower & 1.18 & 0.39 & 0.00 & 20.69 \\
& Middle & 2.28 & 0.98 & 0.00 & 224.14 \\
\hline
\end{tabular}

Participants were divided in two groups (lower and middle management) to their gender, years of experience, age and qualifications. Table 4 indicates that there are no statistical significant differences between middle management and gender, but there are statistically significant differences for lower managers and gender. A significant difference exists for both middle and lower managers regarding to their years of experience, age and qualifications to their POS.

\section{Discussion}

Middle managers in organisations tend to be more mature, experienced and skilled. They have more responsibilities than 
junior managers, and are relatively more focused and accountable. This may be a plausible reason why there are no significant differences regarding gender. Junior managers, on the other hand, operate at a much lower level and may be regarded more as 'trainees'. Given the higher level at which middle managers operate, they are likely to invite higher levels of organisational support. This, according to Eisenberger, Cummings, Armeli \& Lynch (1997) is likely to meet individuals needs for approval, esteem, social identity, recognition and rewards. Once these needs are met, there is higher commitment to the organisation.

The differences between junior and middle managers in terms of years of experience, age, qualifications and experience of POS may be attributable to the fact that the organisation values the contributions of middle managers more than that of junior managers. Also, since middle managers are likely to have worked longer for the organisation and have achieved more job experience, it is likely that they would have received higher organisational support which places them under obligation to 'repay' the organisation (Shore \& Wayne, 1993). In response, the organisation is likely to reciprocate with increased support. Rhoades, Eisenberger \& Armeli (2001) found a relationship between POS and supervisory support and commitment. This suggests that the more supervisory support middle managers enjoy, the more committed they are likely to be. Being at the lowest level of the hierarchy in an organisation junior managers are likely to experience a "diluted' level of organisational support since focus regarding organisational support is mainly attributed to the middle managers.

\section{Conclusion}

The purpose of the study was to establish the perceptions POS of middle and junior managers. The results indicated differences in the perceptions of junior and middle managers. This may perhaps be due to the positions they hold in the hierarchy of the organisation. Notably, the study also confirmed the relationship between POS and supervisory support and commitment. Employees infer organisational support to the extent to which the organisation values their contribution and cares about their well-being and reward such perceived support with increased contribution, performance and loyalty. Organisational support theory holds that in order to assess the benefits of increased work effort, employees form a general perception concerning the extent to which the organization values their contributions and their well-being. Hence, favorable or positive POS is reciprocal as it would increase employee moral obligation to assist the organisation to reach its objectives. This mutual relationship between organisation and employee will bring about return on investment for both the organisation and employees.

\section{References}

Adonis, W. A. (2011). The management of junior football development programmes in selected professional football clubs in Gauteng. Minor Dissertation, University of Johannesburg.

Allen, M. W., Armstrong, D. J., Reid, M. F. \& Riemenschneider, C. K. (2008). Factors impacting the perceived organizational support of IT employees. Information and Management 45, 556-563.

Allen, T. D. (2001). Family-supportive work environments: The role of organizational perceptions. Journal of Vocational Behavior, 58(3), 414-435.

Allen, T. D., Eby, L. T., Poteet, M. L., Lentz, E. \& Lima, L. (2004). Career benefits associated with mentoring for protégés: A metaanalysis. Journal of Applied Psychology, 89, 127-136.

Aselage, J. \& Eisenberger, R. (2003). Perceived organizational support and psychological contracts: A theoretical integration. Journal of Organizational Behavior, 24, 491-509.

Baranik, L. E., Roling, E. A., \& Eby, L. T. (2010). Why does mentoring work? The role of perceived organizational support. Journal of Vocational Behavior, 76, 366-373.

Beehr, T. A., Jex, S. M., Stacy, B. A. \& Murray, M. A. (2000). Work stressors and co-worker support as predictors of individual strain and job performance. Journal of Organizational Behavior, 21, 391-405.

Colakoglu, U., Culha, O. \& Atay, H. (2010). The effects of perceived organisational support on employees' affective outcomes: Evidence from the hotel industry. Tourism and Hospitality Management, 16(2), 125-150.

Cooper, D. R. \& Schindler, P. S. (2006). Marketing Research. New York: McGraw-Hill.

De Croon, E. M., Sluiter, J. K., Blonk, R. W. B., Broersen, J. P. J. \& Frings-Dresen, M. H. W. (2004). Stressful work, psychological job strain, and turnover: A 2-year prospective cohort study of truck drivers. Journal of Applied Psychology, 89, 442-454.

Eisenberger, R., Cummings, J., Armeli, S. \& Lynch, P. (1997). Perceived organizational support, discretionary treatment, and job satisfaction. Journal of Applied Psychology, 82, 812-820.

Eisenberger, R., Fasolo, P. \& Davis-LaMastro, V. (1990). Perceived organizational support and employee diligence, commitment and innovation. Journal of Applied Psychology, 75, 51-59.

Eisenberger, R., Huntington, R., Hutchison, S. \& Sowa, D. (1986). Perceived organizational support. Journal of Applied Psychology, 71 , 500-507. 
Forret, M. \& de Janasz, S. (2005). Perceptions of an organization's culture for work and family: Do mentors make a difference? Career Development International, 10(6/7), 478-492.

Ghani, M. A. (2006). Hospitality and tourism education in the making. Journal of Teaching in Travel and Tourism, 6(2), 71-87.

Grant-Vallonea, E. J. \& Ensherb, E. A. (2001). An examination of work and personal life conflict, organizational support, and employee health among international expatriates. International Journal of Intercultural Relations, 25, 261-278.

Hair, J. F. Jr., Anderson, R. E., Tatham, R. L. \& Black, W. C. (1998). Multivariate Data Analysis (5th Edition).Upper Saddle River, NJ: Prentice Hall.

Hardy, G.E., Woods, D. \& Wall, T.D. (2003).The impact of psychological distress on absence from work. Journal of Applied Psychology, 88, 306-314.

Hoye, R., Smith, A., Stewart, B., Nicholson, M. \& Westrebeek, H. (2005). Sport Management: Principles and Applications. Oxford: Butterworth-Heinemann.

Johnston, J. (1995). The determinants of service quality: satisfiers and dissatisfies. International Journal of Service Industry Management, 6(5), 53-71.

Kanaga, K. \& Browning, H. (2007). Maintaining Team Performance, Center for Creative Leadership. Ideas in to Action Guidebooks: Electronic Books.

Kumar, R. (2011). Research Methodology: A Step-by-Step Guide for Beginners (3rded). University of Western Australia: Sage Publications.

Malhotra, N. (2007). Marketing Research: An Applied Orientation (5thed.). New Jersey: Prentice Hall.

Mauno, S., Kinnunen, U. \& Piitulainen, S. (2005). Work-family culture in four organizations in Finland. Community. Work and Family, 8(2), 115-140.

Mesmer-Magnus, J. R., \& Viswesvaran, C. (2006). How family-friendly work environments affect work/family conflict: A meta-analytic examination. Journal of Labor Research, 27(4), 555-574.

O'Neill, J. W., Harrison, M. M., Cleveland, J., Almeida, D., Stawski, R. \& Crouter, A. C. (2009). Work-family climate, organizational commitment, and turnover: Multilevel contagion effects of leaders. Journal of Vocational Behavior, 74(1), 18-29.

Orpen, C. (1997). The effects of formal mentoring on employee work motivation, organizational commitment, and job performance. The Learning Organization, 4, 53-60.

Rhoades, L. \& Eisenberger, R. (2002). Perceived organizational support: A review of the literature. Journal of Applied Psychology, 87, 698-714.

Rhoades, L., Eisenberger, R. \& Armeli, S. (2001). Affective commitment to the organization: The contribution of perceived organizational support. Journal of Applied Psychology, 86, 825-836.

Saayman, M. \& Rossouw, R. (2008). The economic value of the 2010 Soccer World Cup. Retrieved from: http://www.actacommercii.co.za/index.php/acta/article/viewFile/55/55.2014/03/12.

Shore, L. M. \& Shore, T. H. (1995). Perceived organizational support and organizational justice. In R.S. Cropanzano\& K.M. Kacmar (Eds.), Organizational Politics, Justice and Support: Managing the Social Climate of the Workplace (pp. 149-164). Westport, CT: Quorum.

Shore, L. M. \& Tetrick, L. E. (1991).A construct validity study of the survey of perceived organizational support. Journal of Applied Psychology, 76, 637-643.

Shore, L. M. \& Wayne, S. J. (1993). Commitment and employee behavior: Comparison of affective commitment and continuance commitment with perceived organizational support. Journal of Applied Psychology, 78, 774-780.

SPSS. (2014). IBM SPSS Statistics for Windows, Version 22.0. Armonk, NY: IBM Corp.

Tabachnick, B. G. \& Fidell, L. S. (2001).Using Multivariate Statistics (4thed.). Boston, MA: Allyn and Bacon.

Valcour, M., Ollier-Malaterre, A., Matz-Costa, C., Pitt-Catsouphes, M. \& Brown, M. (2011). Influences on employee perceptions of organizational work-life support: Signals and resources. Journal of Vocational Behavior, 79, 588-595.

Woodman, T. \& Hardy, L. (2001).A case study of organizational stress in elite sport. Journal of Applied Sport Psychology, 13(2), 207238. 